\title{
Skull Base Calcifying Pseudoneoplasms of the Neuraxis: Two Case Reports and a Systematic Review of the Literature
}

\author{
Kaiyun Yang (iD, Kesava Reddy, Yosef Ellenbogen (1D, Bill Hao Wang (i), \\ Michel W. Bojanowski, Jian-Qiang Lu (iD
}

\begin{abstract}
Background: Calcifying pseudoneoplasm of the neuraxis (CAPNON) is a rare tumefactive lesion. CAPNONs can mimic calcified meningiomas at the skull base. Methods: Here, we report two cases of CAPNON and present a systematic review of the literature on skull base CAPNONs, to compare CAPNONs with calcified meningiomas. Results: Case 1: A 57-year-old man presented with rightsided lower cranial neuropathies and gait ataxia. He underwent a subtotal resection of a right cerebellopontine angle lesion, with significant improvement of his gait ataxia. However, his cranial neuropathies persisted. Pathological examination of the lesion was diagnostic of CAPNON, with the entrapped nerve fibers identified at the periphery of the lesion, correlating with the patient's cranial neuropathy. Case 2: A 70-year-old man presented with progressive headache, gait difficulty, and cognitive impairment. He underwent a frontotemporal craniotomy for a near-total resection of his right basal frontal CAPNON. He remained neurologically stable 7 years after the initial resection without evidence of disease recurrence. We analyzed 24 reported CAPNONs at the skull base in our systematic review of the literature. Cranial neuropathies were present in $11(45.8 \%)$ patients. Outcomes regarding cranial neuropathies were documented in six patients: two had sacrifice of the nerve function with surgical approaches and four had persistent cranial neuropathies. Conclusion: While CAPNON can radiologically and grossly mimic calcified meningiomas, they are two distinctly different pathologies. CAPNONs located at the skull base are commonly associated with cranial neuropathies, which may be difficult to reverse despite surgical intervention.
\end{abstract}

RÉSUMÉ : Des pseudo tumeurs calcifiantes du névraxe à la base du crâne : deux études de cas et une revue systématique de la littérature. Contexte : Les pseudo tumeurs calcifiantes du névraxe (PTCN ou calcifying pseudoneoplasm of the neuraxis) sont des lésions tumorales peu fréquentes. Elles ont aussi la particularité de ressembler aux méningiomes calcifiés présents à la base du crâne. Méthodes : Nous voulons ici faire état de deux cas de PTCN et procéder à une revue systématique de la littérature portant sur les PTCN à la base du crâne, ce qui nous permettra de les comparer aux méningiomes calcifiés. Résultats : Cas $\mathrm{n}^{\mathrm{o}} 1$ : un homme âgé de 57 ans atteint de neuropathies dans la partie droite inférieure du crâne et d'ataxie de la démarche. Il a été soumis à une ablation partielle d'une tumeur de l'angle droit ponto-cérébelleux, ce qui a entraîné une amélioration notable de sa démarche. Il convient toutefois de mentionner que ces neuropathies n'ont pas disparu. Un examen pathologique de sa lésion tumorale a révélé qu'il s'agissait d'une PTCN, les fibres nerveuses piégées ayant été identifiées à la périphérie de la tumeur, ce qui nous permet d'établir une corrélation avec les neuropathies du patient. Cas $\mathrm{n}^{\circ} 2$ : un homme âgé de 70 ans atteint de céphalée progressive et souffrant de difficultés de la démarche et de trouble cognitif. Il a été soumis à une craniotomie fronto-temporale entraînant une ablation presque complète d'une PTCN située à droite de la base du crâne. Son état de santé neurologique est par la suite demeuré stable pendant sept ans sans qu'on ait des preuves de récurrence de la maladie. Au total, nous avons analysé 24 cas de PTCN à la base du crâne dans notre revue systématique de littérature. Des neuropathies crâniennes étaient présentes chez 11 patients, soit 45,8 \% d'entre eux. L'évolution de l'état de santé des patients atteints de neuropathies crâniennes a été documentée chez six d'entre eux : deux ont vu leur fonction nerveuse être sacrifiée avec des approches chirurgicales tandis que les quatre autres ont continué à souffrir de neuropathies crâniennes. Conclusion : Même si les PTCN peuvent véritablement ressembler aux méningiomes calcifiés, notamment quand on les observe pendant un examen radiologique, il s'agit de deux pathologies nettement différentes. Les PTCN situées à la base du crâne sont aussi généralement associées aux neuropathies crâniennes, état de fait qui pourrait être difficile à renverser malgré des interventions chirurgicales.

Keywords: Calcifying pseudoneoplasm of the neuraxis, Cranial neuropathy, Epithelial membrane antigen, Meningioma mimicker, Skull base doi: $10.1017 / \operatorname{cjn} .2019 .339$

Can J Neurol Sci. 2020; 47: 389-397

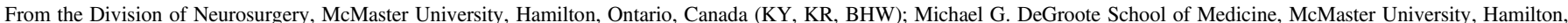

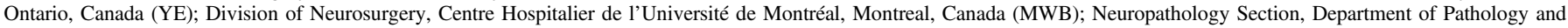
Molecular Medicine, Hamilton Health Sciences and McMaster University, Hamilton, Ontario, Canada (JQL)

Received August 18, 2019. Final Revisions Submitted December 4, 2019. Date of Acceptance December 7, 2019.

Correspondence to: Kaiyun Yang, Division of Neurosurgery, Department of Surgery, McMaster University, 1280 Main Street W, Hamilton, ON L8S 4L8, Canada.

Email: kaiyun.yang@medportal.ca 

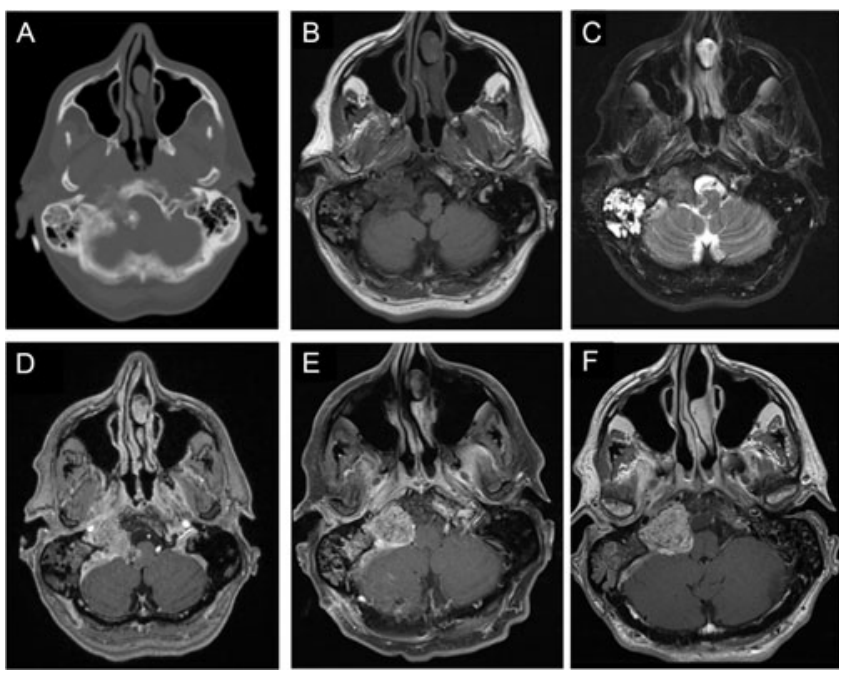

Figure 1: Imaging of a right cerebellopontine angle (CPA) calcifying pseudoneoplasm of the neuraxis (CAPNON). Preoperative computed tomography $(C T)$ of the head revealed a heavily calcified lesion within the right CPA involving right jugular foramen and hypoglossal canal, with medullary compression (A); on magnetic resonance imaging (MRI), this lesion was hypointense on T1-weighted images $(B)$, isointense on T2-weighted images $(C)$, and avidly enhancing with contrast $(D)$, not associated with significant vasogenic edema. Postoperative MRI demonstrated a CAPNON residual in the jugular foramen, along with improved mass effect on the medulla $(E)$. A 15-month follow-up MRI revealed slight progression in the size of right jugular foramen CAPNON $(F)$.

\section{INTRODUCTION}

Calcifying pseudoneoplasm of the neuraxis (CAPNON) was initially reported as a brain calcification by Miller in 1922 and later described as a type of osseous metaplasia by Rhodes and Davis in $1978 .^{1,2}$ It is hypothesized to be a reactive proliferative process possibly associated with inflammation and/or injury, but its etiology and pathogenesis remain poorly understood. ${ }^{3}$ CAPNON can occur at any locations of the central nervous system, including the brain and spine, both intra-axial and extra-axial, with only a number of cases reported at the skull base. ${ }^{3-6}$ In these cases, they are commonly mistaken as calcified meningiomas prior to surgical intervention. ${ }^{3,4,7-10}$ Here, we report two CAPNON lesions located at the skull base, and review skull base CAPNONs reported in the literature, with comparisons of CAPNONs and calcified meningiomas.

\section{Case Report}

Case 1

\section{History and Examination}

A previously healthy 57-year-old man with a past medical history significant for well-controlled asthma presented with 2 months of hoarseness, dysphagia, and gait imbalance. On physical exam, he had right-sided cranial nerves (CNs) IX, X, $\mathrm{XI}$, XII palsies, as well as gait ataxia. Computed tomography (CT) of the head revealed a heavily calcified lesion within the right cerebellopontine angle (CPA), which seemed to originate from petrous temporal bone and condylar part of occipital bone with secondary involvement of right jugular foramen and hypoglossal canal, causing medulla compression (Figure 1A and B).
On magnetic resonance imaging (MRI), this lesion was hypointense on T1-weighted images (T1WI; Figure 1B), isointense on T2-weighted images (T2WI; Figure 1C), and avidly enhancing with gadolinium (Figure 1C), without significant vasogenic edema. This was initially thought to be a meningioma, despite the absence of a dural tail. The portion centered in the right jugular foramen measured $3.5 \times 2.1 \times 2.0 \mathrm{~cm}$ (Figure $1 \mathrm{~B}-\mathrm{D}$ ). Interestingly, CT and MRI also revealed diffuse right mastoid effusion; however, the patient had no subjective symptoms corresponding to this finding (Figure $1 \mathrm{~A}-\mathrm{C}$ ).

\section{Operation}

We performed a right-sided far-lateral approach for debulking of this lesion with electrophysiological monitoring of somatosensory evoked potential (SSEP), motor evoked potential (MEP), and electromyography of the lower CNs. Multiple areas of confluent calcification were seen within the right CPA. The rootlets of CN XI and XII were identified and preserved. However, we could not identify CN IX and X. Given that the lesion was firm and calcified and that $\mathrm{CN}$ XI/XII were adherent to the lesion and CN IX/X were not clearly identified, only the portion of the lesion compressing the medulla was removed to avoid worsening cranial neuropathies. Of note, no reduction in SSEP or MEP occurred during the operation. A postoperative MRI demonstrated a $3.1 \times 2.3 \times 2.0 \mathrm{~cm}$ residual in the jugular foramen, along with improved mass effect on the medulla (Figure 1F).

\section{Pathological Findings}

Pathological examination of the resected tissue revealed a fibroosseous lesion with cores of amorphous to fibrillary materials, peripheral palisading of spindle to epithelioid cells, multifocal calcifications and ossifications, as well as occasional multinucleated giant cells (Figure 2A and B), which was diagnostic of CAPNON. Immunohistochemistry showed focally scattered CD68-positive macrophages including multinucleated giant cells (Figure 2C) and vimentin positivity in most spindle to epithelioid cells (Figure 2D). Neurofilament protein (NFP) immunostaining demonstrated focally positive axons at the periphery of this lesion, suggestive of $\mathrm{CN}$ involvement and correlating with the clinical findings of cranial neuropathies (Figure 2E). The lesion exhibited limited epithelial membrane antigen (EMA) positivity in cells or membranes at the periphery of amorphous core (Figure $2 \mathrm{~F}$ ).

\section{Postoperative Course}

Postoperatively, the patient showed significant improvement in his ataxia, but his cranial neuropathies persisted. At 15-months postoperatively, there was radiographic progression of the disease, with the residual lesion measuring $3.2 \times 2.5 \times 2.1 \mathrm{~cm}$ around the right jugular foramen (Figure 1G). However, the patient remained independent and well clinically.

\section{Case 2}

This case was previously reported by Kocovski et al. ${ }^{11}$ in our institution - here it is revisited with detailed history, perioperative information, additional pathological examination, and long-term follow-up. 


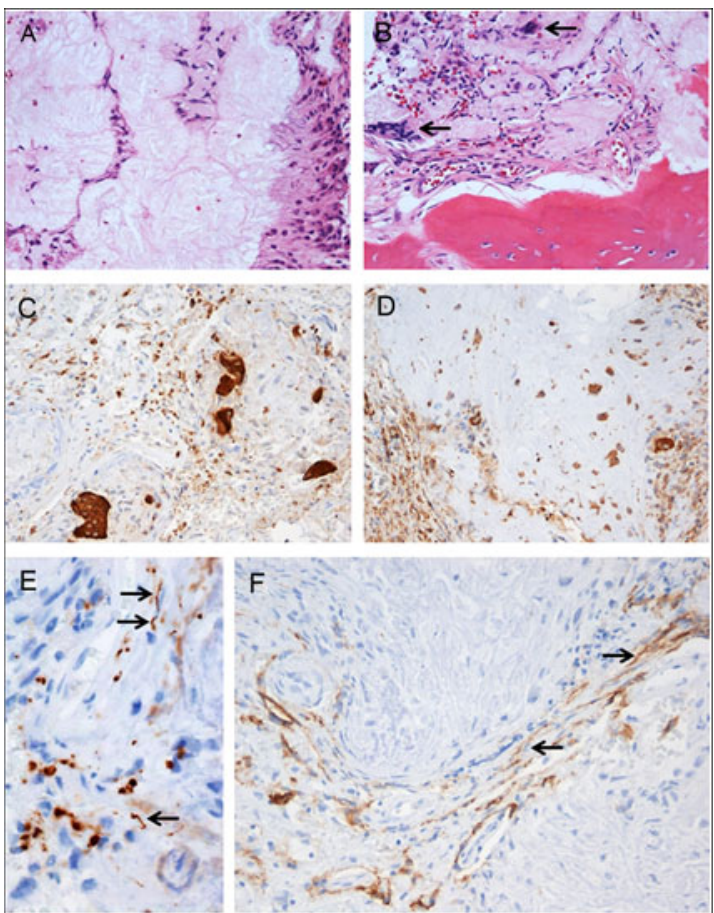

Figure 2: Photomicrographs of the right cerebellopontine angle calcifying pseudoneoplasm of the neuraxis. The lesion contained cores of granular amorphous to fibrillary materials with peripheral palisading spindle to epithelioid cells $(A)$, calcification/ossification, and occasional multinucleated giant cells ( $B$, arrows). Immunohistochemistry revealed focally scattered CD68-positive macrophages including multinucleated giant cells $(C)$, vimentin+ in most spindle to epithelioid cells $(D)$, peripherally located NFP+ axons (E, arrows pointing longitudinally sectioned axons; transversely sectioned axons shown as positive dots), and limited EMA+ cells or membranes at the periphery of amorphous core $(F$, arrows pointing the membranes). Original magnification, $\times 200$ $(A-D, F)$, and $\times 400(E)$.

\section{History and Examination}

A 70-year-old man was referred to neurosurgery clinic with 4 years of progressive headache, gait difficulty with falls, confusion, and mood changes. His past medical history was significant for medication-controlled seizures secondary to remote encephalitis caused by West Niles virus, hypertension, and obstructive sleep apnea. His physical examination revealed no focal neurological deficits except a short stride length in his gait. He scored 23/30 on the Montreal Cognitive Assessment. ${ }^{12}$

CT of the head revealed a well-circumscribed heavily calcified mass, measuring $2.4 \times 2.6 \times 1.8 \mathrm{~cm}$, centered within the right basal frontal lobe, with moderate perilesional vasogenic edema (Figure 3A). On MRI, this mass was hypointense on both T1WI and T2WI, with patchy central T2 hyperintensity, and peripheral enhancement (Figure 3B-D), with no evidence of a dural tail. The lesion was in close proximity to the right internal carotid artery (ICA), proximal middle cerebral artery (MCA), and anterior cerebral artery (ACA) (Figure 3D). It was also mildly displacing the prechiasmic segment of the right optic nerve (Figure $3 \mathrm{C}$ ). There was encephalomalacia within the anterior left temporal lobe with associated ex vacuo dilatation of the temporal horn, which may be a consequence of his previous encephalitis (Figure $3 \mathrm{~A}$ and $\mathrm{C}$ ).
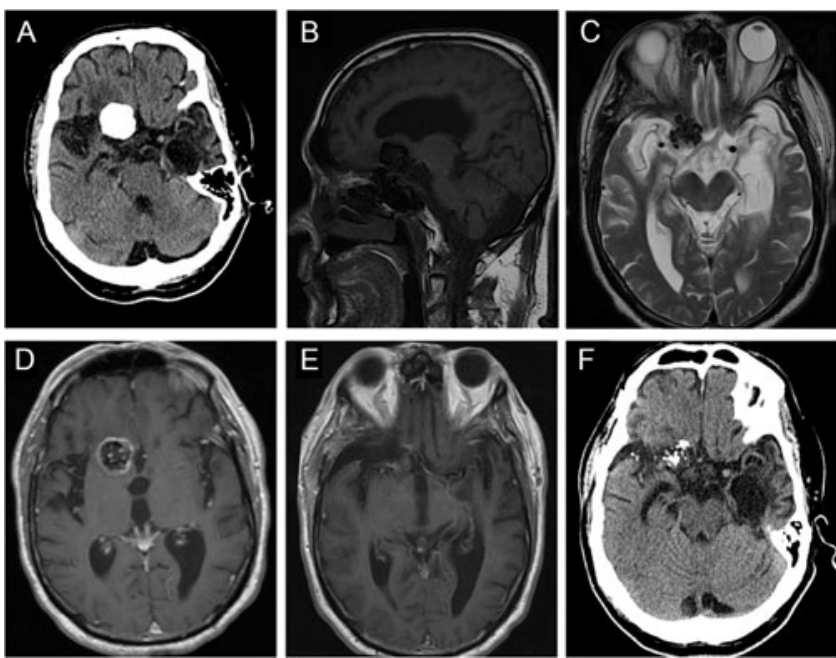

Figure 3: Imaging of a right basal frontal calcifying pseudoneoplasm of the neuraxis. (A) Preoperative axial computed tomography (CT) revealed a $2.4 \times 2.6 \times 1.8 \mathrm{~cm}$ well-circumscribed, lobulated, densely calcified lesion centered within the anterior skull base, with some perilesional vasogenic edema. (B) This lesion was hypointense on sagittal T1WI. (C) Axial T2WI demonstrated that the lesion was hypointense with patchy central hyperintensity, and causing some displacement of right optic nerve. (D) The mass demonstrated peripheral contrast enhancement and was in close proximity to the right anterior cerebral artery. (E) Postoperative magnetic resonance imaging showed near-total resection of the lesion. (F) Follow-up CT scan showed no progression of the residual disease after 7 years.

\section{Operation}

Given his progressive cognitive decline, surgical resection was recommended. The patient underwent a frontotemporal craniotomy, and the lesion was visualized upon frontal and temporal lobe retraction after sylvian fissure splitting. It was firm, heavily calcified, and could not be mobilized. The lesion was removed in a piecemeal fashion, with the help of the Cavitron Ultrasonic Surgical Aspirator (Integra, bone tip). Rhoton dissectors were used to dissect the right ICA, proximal MCA and ACA, as well as the right optic nerve off the lesion. We left a small amount of residual on the right optic nerve due to difficulty dissecting the lesion off the nerve.

\section{Pathological Findings}

Pathology examination confirmed the lesion to be a CAPNON, with cores of granular amorphous materials and peripheral palisading spindle to epithelioid cells, calcification/ossification, and multinucleated giant cells (Figure 4A). Immunohistochemistry demonstrated focally scattered CD68-positive macrophages (Figure 4B), focally positive vimentin in spindle to epithelioid cells (Figure 4C), and limited EMA positivity only in the cells or membranes at the periphery of amorphous core (Figure 4D).

\section{Postoperative Course}

Postoperative imaging confirmed a near-total resection of this right basal frontal CAPNON (Figure 3E). On postoperative examination, the patient's headache improved, and he did not sustain any new focal neurological deficits. However, he continued to have progressive global neurological decline including gait difficulty and cognitive decline and required a nursing home 

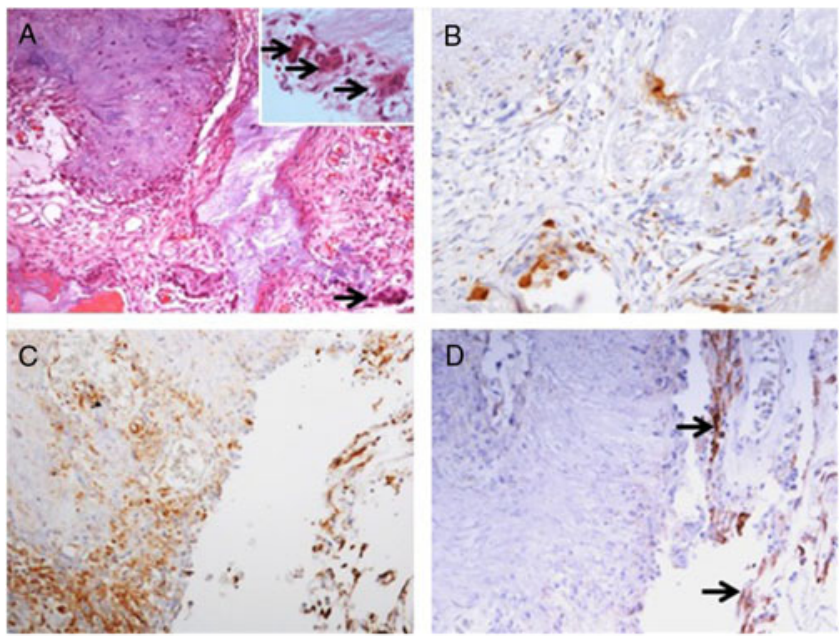

Figure 4: Photomicrographs of the right basal frontal calcifying pseudoneoplasm of the neuraxis. The skull base lesion consisted of cores of granular amorphous materials with peripheral palisading spindle to epithelioid cells, calcification/ossification, and multinucleated giant cells $(A$, arrows including three in an inset with higher magnification). Immunohistochemistry revealed focally scattered CD68+ macrophages $(B)$, vimentin + focally in spindle to epithelioid cells $(C)$, and limited EMA+ cells or membranes at periphery of the lesion $(D$, same area as $C$; arrows pointing the membranes). Original magnification, $\times 200(A-D)$.

placement 6 months after the surgical intervention. It is possible that he had an undiagnosed neurodegenerative condition. He remained stable without focal neurological deficits or radiographic evidence of disease progression 7 years later (Figure 3F) when he underwent a head CT due to a ground-level fall.

\section{Literature RevieW}

A systematic review of the literature was conducted on skull base CAPNONs. MEDLINE, EMBASE, and the Cochrane Central Register of Controlled Trials (CENTRAL) were searched from the inception of the database until June 2019. This systematic review is reported in accordance with the Preferred Reporting Items in Systematic Reviews and Meta-Analyses. Search terms included keyword such as "CAPNON" and combinations of the following words: "calcified," "pseudo-neoplasm," "pseudoneoplasm," "pseudo-tumor," "pseudotumor," "neuro-axis," and "neuraxis." Screening of searched titles, abstracts, and full texts was done independently by two reviewers, and any discrepancies that occurred during the title and abstract screening stages were resolved by automatic inclusion to ensure that all relevant publications were not missed.

Our literature search identified 113 potentially relevant records. After abstract and full-text screening, 18 records were identified including 23 unique cases of skull base CAPNONs (Figure 5, Table 1). ${ }^{4,7-11,13-24}$ All 24 patients (including our previously unpublished case) were symptomatic, with $11(45.8 \%)$ patients presenting with cranial neuropathies (Table 1). ${ }^{7-9,13,16,20}$ One patient (Case 5) was managed conservatively, ${ }^{13}$ and one patient (Case 22) underwent a biopsy of the lesion, ${ }^{14}$ while the rest underwent resection of the lesion. Analysis of patients with documented extents of resection revealed that 10 patients underwent gross total resection and 6 underwent subtotal resection of CAPNONs. Among all 24 patients, only 2 patients (Cases 1 and 23) had complete resolution of the symptoms postoperatively, ${ }^{7,22}$ while most patients remained stable.

Among 11 patients with cranial neuropathies, the outcomes of cranial neuropathies were documented in 6 patients. ${ }^{7,9,16,20}$ Two

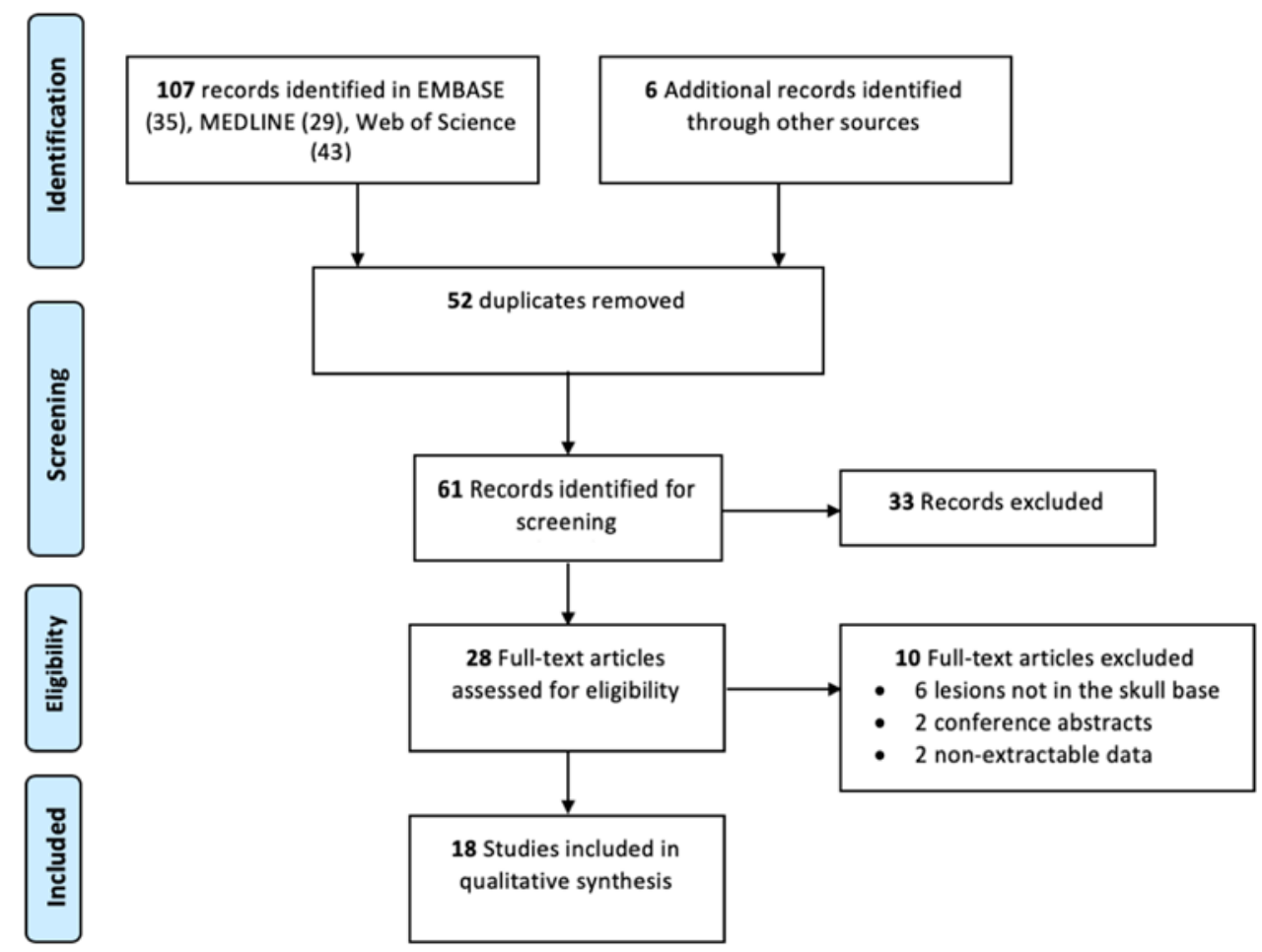

Figure 5: Preferred Reporting Items in Systematic Reviews and Meta-Analyses flow diagram outlining the search strategy results from initial search to included studies. 
Table 1: Skull base CAPNONs reported in the literature

\begin{tabular}{|c|c|c|c|c|c|c|c|c|c|c|c|c|}
\hline Case & Report & Age & Sex & Symptom & $\begin{array}{c}\text { Cranial } \\
\text { neuropathy }\end{array}$ & Location & $\begin{array}{c}\text { Contrast } \\
\text { enhancement }\end{array}$ & Edema & Treatment & $\begin{array}{c}\text { Follow-up } \\
\text { (months) }\end{array}$ & Outcome & Recurrence \\
\hline 1 & Garen et al. (1989) & 44 & M & $\begin{array}{l}\text { Atypical facial } \\
\text { pain }\end{array}$ & Yes & Right Meckel's cave & ND & ND & GTR & 132 & Pain resolved & ND \\
\hline 2 & $\begin{array}{l}\text { Bertoni et al. } \\
\text { (1990) }\end{array}$ & 31 & M & $\begin{array}{l}\text { Headache, jugular } \\
\text { foramen } \\
\text { syndrome }\end{array}$ & Yes & $\begin{array}{l}\text { Left jugular foramen, } \\
\text { cerebellopontine } \\
\text { angle }\end{array}$ & ND & ND & Resection & 156 & ND & 3 years \\
\hline 3 & $\begin{array}{l}\text { Bertoni et al. } \\
(1990)\end{array}$ & 50 & M & $\begin{array}{l}\text { Right neck and } \\
\text { occipital area } \\
\text { pain }\end{array}$ & No & Foramen magnum & ND & ND & STR & 42 & ND & None \\
\hline 4 & $\begin{array}{l}\text { Bertoni et al. } \\
\text { (1990) }\end{array}$ & 48 & M & $\begin{array}{l}\text { Right XI cranial } \\
\text { nerve paralysis }\end{array}$ & Yes & $\begin{array}{l}\text { Right cerebellar tonsil, } \\
\text { spinal accessory } \\
\text { nerve involvement }\end{array}$ & ND & ND & GTR & 228 & ND & None \\
\hline 5 & $\begin{array}{l}\text { Bertoni et al. } \\
\text { (1990) }\end{array}$ & 45 & F & $\begin{array}{l}\text { Multiple cranial } \\
\text { nerve palsies }\end{array}$ & Yes & $\begin{array}{l}\text { Right sphenoid, } \\
\text { occipital bone, sellar, } \\
\text { foramen magnum }\end{array}$ & ND & ND & Nonsurgical & $\mathrm{n} / \mathrm{a}$ & N/A & None \\
\hline 6 & $\begin{array}{l}\text { Bertoni et al. } \\
\text { (1990) }\end{array}$ & 58 & M & $\begin{array}{l}\text { Hoarseness, } \\
\text { hearing loss }\end{array}$ & Yes & Jugular foramen & $\mathrm{ND}$ & ND & Resection & $\begin{array}{l}\text { Lost to follow- } \\
\text { up }\end{array}$ & ND & ND \\
\hline 7 & Qian et al. (1999) & 49 & $\mathrm{M}$ & Tetraparesis & No & Clivus, upper cervical & ND & ND & GTR & 90 & ND & None \\
\hline 8 & Shrier et al. (1999) & 59 & M & Tetraparesis & No & Foramen magnum & Yes, heterogenous & Minimal & GTR & 24 & Stable & None \\
\hline 9 & $\begin{array}{l}\text { Hodges et al. } \\
\text { (2011) }\end{array}$ & 34 & M & Headache, tinnitis & Yes & $\begin{array}{l}\text { Left cerebellopontine } \\
\text { angle }\end{array}$ & Yes, peripheral & Minimal & STR & 7 & $\begin{array}{l}\text { Stable with persistent } \\
\text { hypoglossal palsy }\end{array}$ & None \\
\hline 10 & $\begin{array}{l}\text { Ozdemir et al. } \\
(2011)\end{array}$ & 53 & M & $\begin{array}{l}\text { Left facial pain, } \\
\text { left leg weakness }\end{array}$ & No & Left foramen magnum & $\begin{array}{l}\text { Strong, } \\
\text { heterogenous }\end{array}$ & Yes & Resection & ND & ND & ND \\
\hline 11 & $\begin{array}{l}\text { Fletcher et al. } \\
(2012)\end{array}$ & 19 & M & $\begin{array}{c}\text { Frontal headache, } \\
\text { nasal discharge }\end{array}$ & No & $\begin{array}{l}\text { Left ethmoid sinus, } \\
\text { anterior skull base }\end{array}$ & Minimal, irregular & ND & Resection & ND & ND & ND \\
\hline 12 & $\begin{array}{l}\text { Muccio et al. } \\
\text { (2012) }\end{array}$ & 55 & $\mathrm{~F}$ & Neck pain & No & $\begin{array}{l}\text { Right foramen } \\
\text { magnum }\end{array}$ & Minimal, irregular & No & GTR & 14 & Stable & None \\
\hline 13 & $\begin{array}{l}\text { Nonaka et al. } \\
(2012)\end{array}$ & 56 & M & $\begin{array}{l}\text { Chronic right ear } \\
\text { infections, right } \\
\text { facial pain/ } \\
\text { numbness }\end{array}$ & Yes & $\begin{array}{l}\text { Right infratemporal } \\
\text { fossa }\end{array}$ & & No & GTR & ND & Stable & ND \\
\hline 14 & $\begin{array}{l}\text { Nonaka et al. } \\
(2012)\end{array}$ & 35 & $\mathrm{M}$ & $\begin{array}{l}\text { Occipital } \\
\text { headaches, } \\
\text { dizziness }\end{array}$ & Yes & $\begin{array}{l}\text { Left clivus, posterior } \\
\text { fossa }\end{array}$ & Minimal, irregular & Minimal & STR & 6 & Stable & None \\
\hline 15 & Kerr et al. (2013) & 56 & M & Headache & No & $\begin{array}{l}\text { Right } \\
\text { cerebellomedullary } \\
\text { angle }\end{array}$ & $\begin{array}{c}\text { Mild peripheral } \\
\text { enhancement }\end{array}$ & Yes & STR & 6 & $\begin{array}{l}\text { Dysphagia, } \\
\text { hoarsenseness }\end{array}$ & None \\
\hline
\end{tabular}


Table 1: (Continued)

\begin{tabular}{|c|c|c|c|c|c|c|c|c|c|c|c|c|}
\hline Case & Report & Age & Sex & Symptom & $\begin{array}{c}\text { Cranial } \\
\text { neuropathy }\end{array}$ & Location & $\begin{array}{c}\text { Contrast } \\
\text { enhancement }\end{array}$ & Edema & Treatment & $\begin{array}{c}\begin{array}{c}\text { Follow-up } \\
\text { (months) }\end{array} \\
\end{array}$ & Outcome & Recurrence \\
\hline 16 & Lu et al. (2015) & ND & ND & $\begin{array}{r}\text { Suboccipital } \\
\text { headaches }\end{array}$ & No & $\begin{array}{l}\text { Right } \\
\text { cerebellomedullary } \\
\text { angle }\end{array}$ & Minimal, irregular & Minimal & GTR & ND & ND & ND \\
\hline 17 & $\begin{array}{l}\text { Wisniewski et al. } \\
\text { (2015) }\end{array}$ & 29 & M & $\begin{array}{l}\text { Headaches, } \\
\text { impaired head } \\
\text { rotation }\end{array}$ & No & $\begin{array}{l}\text { Right foramen } \\
\text { magnum }\end{array}$ & $\begin{array}{l}\text { Minimal, } \\
\text { peripheral }\end{array}$ & Minimal & GTR & 24 & Stable & ND \\
\hline 18 & $\begin{array}{l}\text { Alshareef et al. } \\
\text { (2016) }\end{array}$ & 59 & $\mathrm{~F}$ & Incidental & No & $\begin{array}{l}\text { Right } \\
\text { cerebellomedullary } \\
\text { angle, foramen } \\
\text { magnum }\end{array}$ & Strong & Yes & STR & 12 & Stable & None \\
\hline 19 & $\begin{array}{l}\text { Ghaemi et al. } \\
\text { (2016) }\end{array}$ & 18 & ND & $\begin{array}{l}\text { Headache and } \\
\text { diplopia }\end{array}$ & Yes & Interpeduncular cistern & $\begin{array}{l}\text { Minimal, } \\
\text { peripheral }\end{array}$ & No & Resection & ND & ND & ND \\
\hline 20 & $\begin{array}{l}\text { Nussbaum et al. } \\
\text { (2018) }\end{array}$ & 39 & $\mathrm{~F}$ & $\begin{array}{l}\text { Right-sided } \\
\text { hearing loss, } \\
\text { tinnitus }\end{array}$ & Yes & $\begin{array}{l}\text { Right petrous apex, } \\
\text { internal auditory } \\
\text { canal, jugular } \\
\text { foramen }\end{array}$ & Minimal, irregular & No & GTR & ND & $\begin{array}{l}\text { Right-sided complete } \\
\text { hearing loss }\end{array}$ & ND \\
\hline 21 & Blood et al. (2018) & 65 & $\mathrm{~F}$ & Incidental & No & $\begin{array}{l}\text { Right frontal sinus and } \\
\text { superior orbital rim }\end{array}$ & ND & ND & Biopsy & ND & N/A & None \\
\hline 22 & Peker et al. (2018) & 58 & $\mathrm{~F}$ & Dizziness & No & $\begin{array}{l}\text { Left lateral } \\
\text { cerebellomedullary } \\
\text { junction }\end{array}$ & Yes, peripheral & Yes, mild & GTR & 12 & Dizziness resolved & None \\
\hline $23 *$ & $\begin{array}{l}\text { Kocovski et al. } \\
\text { (2015) }\end{array}$ & 70 & M & $\begin{array}{l}\text { Headache, } \\
\text { cognitive } \\
\text { impairment }\end{array}$ & No & $\begin{array}{l}\text { Right anterior skull } \\
\text { base }\end{array}$ & ND & No & Resection & ND & Improved headache & None \\
\hline 24 & Current case & 57 & M & $\begin{array}{l}\text { Hoarseness, } \\
\text { dysphagia, ataxia }\end{array}$ & Yes & $\begin{array}{l}\text { Right cerebellopontine } \\
\text { angle }\end{array}$ & Strong & No & STR & 15 & Stable & None \\
\hline
\end{tabular}

$\mathrm{CAPNON}=$ calcifying pseudoneoplasm of neuraxis; $\mathrm{F}=$ female; $\mathrm{GTR}=$ gross total resection; $\mathrm{M}=$ male; $\mathrm{STR}=$ subtotal resection; $\mathrm{ND}=$ not documented .

*Case 23 was previously published in our center and reanalyzed in the present study. 
Table 2: Comparisons of CAPNON, psammomatous meningioma, and metaplastic meningioma

\begin{tabular}{|c|c|c|c|}
\hline & CAPNON & Psammomatous meningioma & Metaplastic meningioma \\
\hline Location & Intra/extra-axial in the brain and spine & $\begin{array}{l}\text { Usually spinal location, and cerebral } \\
\text { convexity }\end{array}$ & Spinal and intracranial locations \\
\hline T1WI & Hypointense & Isointense & Iso- or hypointense \\
\hline T2WI & Hypointense & Mixed hypo- and hyperintensity & Hypointense or mixed intensity \\
\hline Perilesional edema & Rare & Uncommon & Rare \\
\hline Enhancement & $\begin{array}{l}\text { Peripheral enhancement, occasionally } \\
\text { homogenous enhancement }\end{array}$ & Moderate enhancement & Homogenous enhancement \\
\hline Dural tail & Absent & Present & Present \\
\hline Associated adjacent changes on imaging & Inflammatory/reactive changes & Bony hyperostosis & Bony hyperostosis \\
\hline Gross appearance at operation & Heavily calcified masses & Heavily calcified masses & $\begin{array}{l}\text { Heavily calcified masses with dystrophic } \\
\text { ossifications }\end{array}$ \\
\hline Hematoxylin and Eosin staining & $\begin{array}{l}\text { Chondromyxoid or granular amorphous } \\
\text { cores with palisading spindle to } \\
\text { epithelioid cells, ossification, } \\
\text { calcification, infrequent inflammatory } \\
\text { cells including multinucleated giant cells }\end{array}$ & $\begin{array}{l}\text { Abundant psammoma bodies ( }>50 \% \text { of the } \\
\text { tumor) with intermixed meningothelial } \\
\text { cells }\end{array}$ & $\begin{array}{l}\text { Mesenchymal differentiation with osseous, } \\
\text { cartilaginous, lipomatus, xanthomatous, } \\
\text { and/or myxoid tissue elements, as well as } \\
\text { retained meningothelial cells }\end{array}$ \\
\hline $\begin{array}{l}\text { Epithelial membrane antigen } \\
\text { immunostaining }\end{array}$ & $\begin{array}{l}\text { Limited positivity at the periphery of } \\
\text { lesions, or completely negative lesions (if } \\
\text { not involving the meninges) }\end{array}$ & Positive in meningothelial cells & Positive in meningothelial cells \\
\hline
\end{tabular}

patients had a sacrifice of the $\mathrm{CN}$ function with surgical approaches (Cases 1 and 21), ${ }^{7,20}$ while the remaining four patients (Cases 9, 13, 14, and 24) remained stable with persistent cranial neuropathies. ${ }^{9,16}$ Another patient (Case 15) had new CN $\mathrm{X}$ palsy postoperatively, which was responsive to medical management. ${ }^{17}$ Jugular foramen CAPNONs were reported in three other cases, of which two cases were not followed clinically (Cases 6 and 21). ${ }^{13,20}$ The third patient (Case 2) initially underwent an intralesional excision and had disease progression at 3 years requiring repeat surgical intervention. ${ }^{13}$ Notably, this was the only reported case of CAPNON recurrence in the series of 24 patients.

\section{Discussion}

Since the first characterization of CAPNON as an osseofibrous lesion in 1978, over 100 cases of CAPNON have been reported. The average age at presentation is 47 years and a slight male predilection is seen. ${ }^{5}$ With regard to spinal CAPNONs, they are typically located in the epidural space $(81.48 \%){ }^{6}$ In contrast, intracranial CAPNONs are more commonly found intraaxially. ${ }^{4-6}$ In this study, we reviewed a total of 24 cases located at the skull base and discovered a high incidence $(45.8 \%)$ of cranial neuropathies associated with skull base CAPNONs. In our case report of a right CPA CAPNON, we present novel pathological findings of the $\mathrm{CN}$ involvement with NFP-positive entrapped nerve fibers/axons identified at the periphery of the lesion, correlating with clinical cranial neuropathy.

The etiology of CAPNON remains unclear, but a reactive process is favored for its pathogenesis. Our first case was a rightsided CPA CAPNON which occurred in a patient with right-sided mastoid effusion. Our second case was a right basal frontal CAPNON in a patient who had remote encephalitis caused by
West Nile Virus, with the CAPNON adjacent to the areas of encephalomalacia caused by the previous neurological insult. Both of these cases of CAPNONs occurred in the close vicinity to a separate, and possibly preceding infectious/inflammatory process, further supporting the notion that CAPNON is a reactive proliferative process associated with inflammation and/or injury. ${ }^{3}$ In reviewing other published cases of skull base CAPNONs, we found that past medical history was not available in the majority. However, Nonaka et al. published a case of a right-sided infratemporal CAPNON in which their patient presented with chronic right-sided ear infections (Table 1). ${ }^{9}$ While it cannot be concluded that the ear infections preceded the CAPNON, its close vicinity suggests they may be related.

Radiographic differential diagnoses of skull base CAPNONs should include calcified meningioma subtypes, chordoma, chondrosarcoma, schwannoma, granulomatous lesions, and other inflammatory lesions. ${ }^{13}$ The meningioma subtypes, in particular psammomatous and metaplastic meningiomas, should be the top differential diagnoses for a calcified lesion located at the skull base. CAPNONs are often mistaken as calcified meningiomas until a pathological diagnosis is made after surgical intervention. ${ }^{3,4,7-10}$ However, there are some subtle differences in the imaging characteristics between CAPNONs and calcified meningiomas (Table 2). First, the lack of a dural tail on CAPNONs can help distinguish them from calcified meningiomas. Second, CAPNONs are usually hypointense on T1WI and T2WI and perilesional edema is rare. ${ }^{3,5}$ Additionally, the majority of cases of CAPNON demonstrate a peripheral enhancement pattern in contrast to psammomatous and metaplastic meningiomas..$^{5}$ Of note, our right CPA CAPNON is vividly enhancing with contrast, similar to a previous case reported by Alshareef and colleagues. ${ }^{4}$ In contrast, psammomatous meningiomas are often isointense on T1WI and have mixed hypo- and hyperintensity on T2WI, with 
moderate homogeneous enhancement with contrast. Similar to CAPNONs, perilesional edema is uncommon. Additionally, psammomatous meningiomas have a predilection for the spine and cerebral convexity. ${ }^{25}$ Metaplastic meningiomas tend to be iso- or hypointense on T1WI, hypointense or of mixed intensity on T2WI, with homogenous enhancement and rare perilesional edema. ${ }^{26,27}$

Pathologically, CAPNONs are distinctly different from grossly calcified, psammomatous meningiomas and metaplastic meningiomas. CAPNON is typically composed of the following components: (1) chondromyxoid cores containing amorphous to fibrillary materials; (2) peripheral palisading of spindle to epithelioid cells; (3) calcifications and ossifications; and (4) foreignbody reaction with multinucleated giant cells. ${ }^{23}$ Despite high variations in these morphological components, the chondromyxoid cores with calcification seem to be a principal constituent of CAPNON. On the other hand, psammomatous meningiomas consist of abundant psammoma bodies (more than half of the tumor) with intermixed meningothelial cells. ${ }^{25}$ Metaplastic meningiomas are characterized by mesenchymal differentiation including osseous, cartilaginous, lipomatus, xanthomatous, and/or myxoid tissue elements, with retained meningothelial cells in nonmetaplastic areas. ${ }^{26,27}$ EMA immunostaining, a routinely used marker for meningiomas, is positive largely in the retained meningothelial cells in metaplastic and psammomatous meningiomas. In contrast, CAPNONs have limited EMA positivity that is often linear in distribution and typically seen at the periphery of the amorphous cores or the tissue edge of CAPNONs, ${ }^{3}$ which may be reflective of the meningeal involvement in the stroma rather than the constituent of CAPNONs. In the 24 reviewed cases of skull base CAPNONs, EMA immunostaining was positive with or without specified distribution in 6 cases (including our 2 cases), ${ }^{14,15,17,24}$ but negative in 2 cases, ${ }^{16,20}$ and not mentioned in the remaining 16 cases. We speculate that EMA is usually negative in CAPNONs without the meningeal involvement or focally positive in CAPNONs with the meningeal involvement, and its positivity is limited to the meningothelial cells entrapped in CAPNON lesions. Therefore, EMA is a useful pathological marker to differentiate CAPNONs from calcified psammomatous or metaplastic meningiomas (Table 2).

The morbidity associated with CAPNONs arises primarily from mass effect. Intracranial CAPNONs can cause seizures, headaches, vision loss, weakness, pain, and developmental delay. ${ }^{17}$ Additionally, our systematic review of the literature found that CAPNONs at the skull base are associated with a high incidence of cranial neuropathies $(45.8 \%)$. This may be partially explained by mass effect exerted on CNs by the lesion around the narrow neural foramina. It could also be related to the inflammatory nature of CAPNON. As illustrated in our right CPA CAPNON case, nerve axons have been at the periphery of the lesion, which may reflect inflammatory "invasion" of the nerves and explain the high incidence of cranial neuropathies.

The previously reported cases have described a 4- to 17-year monitoring period before progression warranting neurosurgical intervention. ${ }^{5}$ Due to the indolent nature of CAPNONs, very few patients with recurrences have been documented in the literature. In the 24 reviewed cases, only one case of a jugular foramen CAPNON recurred at 3 years requiring repeat operation. $^{13}$

\section{Conclusion}

CAPNONs located at the skull base can mimic calcified meningiomas and is associated with a high incidence of cranial neuropathy. When considering surgical intervention, surgeons should be aware that gross total resection and $\mathrm{CN}$ detachment from CAPNON may be difficult, due to anatomical location of the lesion, associated technical challenge, and possible inflammatory involvement of CNs.

\section{Statement of Authorship}

$\mathrm{KY}, \mathrm{JQL}$, and KR designed the study. KR, BHW, MNB, and JQL provided patient data and analysis. KY and YE extracted the data and wrote the manuscript. All authors critically reviewed and approved the final manuscript.

\section{Disclosures}

The authors report no conflicts of interest concerning the materials or methods used in this study or the findings specified in this paper.

\section{REFERENCES}

1. Rhodes RH, Davis RL. An unusual fibro-osseous component in intracranial lesions. Human Pathol. 1978;9(3):309-19.

2. Miller E. Calculi within the brain. Report of a case of intracranial calcification with successful operation and recovery. Surg Gynecol Obstet. 1922;34:786-9.

3. Aiken AH, Akgun H, Tihan T, Barbaro N, Glastonbury C. Calcifying pseudoneoplasms of the neuraxis: CT, MR imaging, and histologic features. AJNR Am J Neuroradiol. 2009;30(6):1256-60.

4. Alshareef M, Vargas J, Welsh CT, Kalhorn SP. Calcifying pseudoneoplasm of the cervicomedullary junction: case report and a literature review. World Neurosurg. 2016;85:364.e11-18.

5. Barber SM, Low JCM, Johns P, Rich P, MacDonald B, Jones TL. Calcifying pseudoneoplasm of the neuraxis: a case illustrating natural history over 17 years of radiologic surveillance. World Neurosurg. 2018;115:309-19.

6. Garcia Duque S, Medina Lopez D, Ortiz de Mendivil A, Diamantopoulos Fernandez J. Calcifying pseudoneoplasms of the neuraxis: report on four cases and review of the literature. Clin Neurol Neurosurg. 2016;143:116-20.

7. Garen PD, Powers JM, King JS, Perot PL, Jr. Intracranial fibroosseous lesion. Case report. J Neurosurg. 1989;70(3):475-7.

8. Ghaemi J, Wasimi M, Siripurapu R, et al. Calcifying pseudoneoplasm of the neuraxis $(\mathrm{CaPNoN})$ : an unusual cause of third nerve palsy in a teenager. BJR Case Rep. 2016;2(3):20150494.

9. Nonaka Y, Aliabadi HR, Friedman AH, Odere FG, Fukushima T. Calcifying pseudoneoplasms of the skull base presenting with cranial neuropathies: case report and literature review. J Neurol Surg Rep. 2012;73(1):41-7.

10. Shrier DA, Melville D, Millet D, et al. Fibro-osseous lesions involving the brain: MRI. Neuroradiology. 1999;41(1):18-21.

11. Kocovski L, Parasu N, Provias JP, Popovic S. Radiologic and histopathologic features of calcifying pseudoneoplasm of the neural axis. Can Assoc Radiol J. 2015;66(2):108-14.

12. Nasreddine ZS, Phillips NA, Bédirian V, et al. The Montreal Cognitive Assessment, MoCA: a brief screening tool for mild cognitive impairment. J Am Geriatr Soc. 2005;53(4):695-9.

13. Bertoni F, Unni KK, Dahlin DC, Beabout JW, Onofrio BM. Calcifying pseudoneoplasms of the neural axis. J Neurosurg. 1990;72(1):42-48.

14. Blood TC, Rodriguez FJ, Nolan N, Ramanathan M, Jr., Desai SC. Anterior cranial fossa calcifying pseudoneoplasm of the neuroaxis-diagnosis using a transblepharoplasty approach. J Neurol Surg Rep. 2018;79(3):e75-8.

15. Fletcher AM, Greenlee JJ, Chang KE, Smoker WR, Kirby PA, O'Brien EK. Endoscopic resection of calcifying pseudoneoplasm 
of the neuraxis (CAPNON) of the anterior skull base with sinonasal extension. J Clin Neurosci. 2012;19(7):1048-9.

16. Hodges TR, Karikari IO, Nimjee SM, et al. Calcifying pseudoneoplasm of the cerebellopontine angle: case report. Neurosurgery. 2011;69(1 Suppl Operative):onsE117-20.

17. Kerr EE, Borys E, Bobinski M, Shahlaie K. Posterior fossa calcifying pseudoneoplasm of the central nervous system. J Neurosurg. 2013;118(4):896-902.

18. Lu A, Nundkumar A, Greco CM, Shen P. Calcified pseudoneoplasm of the neuraxis. Neurology. 2015;84(22):2289-90.

19. Muccio CF, Cerase A, Leone A, et al. Calcifying pseudoneoplasm of the neuraxis. Two case reports and review of CT and MR findings. Neuroradiol J. 2012;25(4):453-9.

20. Nussbaum ES, Hilton C, Defillo A, et al. Extradural petromastoid calcifying pseudoneoplasm of the neuraxis (CAPNON): case report and literature review. Clin Neurol Neurosurg. 2018; 166:99-106.

21. Ozdemir M, Bozkurt M, Ozgural O, Erden E, Tuna H, Caglar YS. Unusual localization of an unusual tumor: calcifying pseudoneoplasm of the foramen magnum. Clin Neuropathol. 2011;30(1):25-7.

22. Peker HO, Aydin I, Baskaya MK. Calcifying pseudoneoplasm of the neuraxis (CAPNON) in lateral cerebellomedullary junction: clinical image with surgical video. World Neurosurg. 2018;115:206-7.

23. Qian J, Rubio A, Powers JM, et al. Fibro-osseous lesions of the central nervous system: report of four cases and literature review. Am J Surg Pathol. 1999;23(10):1270-5.

24. Wisniewski K, Janczar K, Tybor K, Papierz W, Jaskolski DJ. Calcifying pseudoneoplasm of the foramen magnum - case report and review of the literature. Br J Neurosurg. 2015;29(6):891-3.

25. Liu L, Lu Y, Peng $\mathrm{W}$, et al. Imaging features of intracranial psammomatous meningioma. J Neuroradiol. 2017;44(6):395-9.

26. Caffo M, Caruso G, Barresi V, Tomasello F. Ossified intracranial meningiomas: description of the first series of cases and review of the literature. World Neurosurg. 2016;94:458-64.

27. Tang H, Sun H, Chen H, et al. Clinicopathological analysis of metaplastic meningioma: report of 15 cases in Huashan Hospital. Chin J Cancer Res. 2013;25(1):112-18. 